\section{Ovarian transplant for transgenic rescue}

\section{To the editor:}

I am writing in regard to the recently published article by Dawes and colleagues ${ }^{1}$ that describes using multiple ovarian transplants to rescue a transgenic line of mice. Although it is a very well-written paper, it contains some misleading information that I would like to clarify.

Since 1945, fresh ovary transfer has been used at the Jackson Laboratories for maintaining mouse strains with breeding problems ${ }^{2}$. The technique was first described by Robertson in 1940 (ref. 3). The technique described in the paper by Dawes et al. ${ }^{1}$ was published in 1957 by Stevens ${ }^{4}$ and then modified and described as we currently use it by Cunliffe-Beamer in 1983 (ref. 5).

It is well known that ovary transplantation doesn't require the use of frozen tissue, as Dawes and colleagues ${ }^{1}$ state. In fact, one of the papers ${ }^{6}$ cited by Dawes and colleagues ${ }^{1}$ describes that ovary cryopreservation was a combination of two techniques: ovary transfer and cryopreservation. Many published articles have compared results using fresh versus cryopreserved ovaries, and it is reasonable to state that a fresh organ behaves better than a previously frozen organ for surgical transplantation ${ }^{7-10}$. Therefore, the technique described is not novel.

Jorge M. Sztein, DVM, PhD
Chief Assisted Reproduction Technologies including Cryopreservation Unit National Institutes of Allergy and Infectious Diseases, National Institutes of Health Rockville, $M D$

email:szteinj@niaid.nih.gov

1. Dawes, J., Liu, B., Mars, W., Michalopoulos, G. \& Khillan, J. Multiple ovarian transplants to rescue a transgenic line of mice. Lab Anim. (NY) 39, 191-193 (2010).

2. Russell, W.L. \& Hurst, J.G. Pure strain mice born to hybrid mothers following ovarian transplantation. Proc. Natl. Acad. Sci. USA 31, 267-273 (1945).

3. Robertson, G.A.G. Ovarian transplantation in the house mouse. Proc. Soc. Exp. Biol. Med. 44, 302-304 (1940).

4. Stevens, L.C. A modification of Robertson's technique of homoiotopic ovarian transplantation in mice. Transplant. Bull. 4, 106-107 (1957).

5. Cunliffe-Beamer, T.L. Biomethodology and surgical techniques. in The Mouse in Biomedical Research vol. 3 (eds. Foster, H.L., Small, J.D. \& Fox, J.G.) 419-420 (Academic, New York, 1983).

6. Sztein, J., Sweet, H., Farley, J. \& Mobraaten, L. Cryopreservation and orthotopic transplantation of mouse ovaries: new approach in gamete banking. Biol. Reprod. 58, 1071-1074 (1998).

7. Sztein, J.M., McGregor, T.E., Bedigian, H.J. \& Mobraaten, L.E. Transgenic mouse strain rescue by frozen ovaries. Lab. Anim. Sci. 49, 99-100 (1999).

8. Sztein, J.M., O’Brien, M.J., Farley, J.S., Mobraaten, L.E. \& Eppig, J.J. Rescue of oocytes from antral follicles of cryopreserved mouse ovaries: competence to undergo maturation, embryogenesis, and development to term. Hum. Reprod. 15, 567-571 (2000).

9. Shaw, J.M., Bowles, J., Koopman, P., Wood, E.C. \& Trounson, A.0. Fresh and cryopreserved ovarian tissue samples from donors with lymphoma transmit the cancer to graft recipients. Hum. Reprod. 11, 1668-1673 (1996).

10. Harari, D., Bernard, 0. \& Shaw, J. Rescue of an infertile transgenic line by ovarian transplantation. Transgenics 2, 143-151 (1997).

\section{Khillan responds:}

I would like to emphasize that the article by Dawes and colleagues ${ }^{1}$ describes not only a procedure for ovarian transfer but also an unusual situation that required multigenerational transfers of ovaries to rescue a valuable transgenic line. From time to time, some investigators face a situation where a valuable transgenic line of mice is in jeopardy. Creation of a new line of mice is a huge investment that, apart from being expensive, can take between 6 and 8 months. Moreover, the same transgenic founder can never be recreated. Although ovarian transfer is a well-established procedure, the success cannot always be guaranteed, especially when the amount of available tissue is limited.

In the situation described in our paper, there was only one donor, the transgenic founder female mouse ${ }^{1}$. Under normal circumstances, this one ovarian transfer would be enough to save the transgenic line. However, when we bred this recipient female, the female generated only one transgenic pup (a female) that was of poor health. We were unable to continue the transgenic line by breeding this female transgenic progeny. Upon dissection, we found that the ovaries of this transgenic progeny were poorly developed. We transplanted the ovaries from this female into a recipient female. Though the starting ovarian tissue was of poor quality, we were able to breed the recipient female, to obtain transgenic progeny and eventually to establish a transgenic line. This article provides valuable information that may help investigators save time and money and precious transgenic lines that otherwise may be lost.

\section{Jaspal S. Khillan, PhD}

Visiting Research Associate Professor

Department of Microbiology and Molecular Genetics

University of Pittsburgh

Pittsburgh, $P A$

1. Dawes, J., Liu, B., Mars, W., Michalopoulos, G. \& Khillan, J. Multiple ovarian transplants to rescue a transgenic line of mice. Lab Anim. (NY) 39, 191-193 (2010). 